\title{
ANALISIS PROSES PEMBELAJARAN BAHASA ARAB PADA TINGKAT TSANAWIYAH DI PONDOK PESANTREN TA'MIRUL ISLAM
}

\author{
Nurul Hidayatul Amalina ${ }^{1}$ Muh. Nashirudin ${ }^{2}$ \\ 1 Pondok Pesantren Ta'mirul Islam, Jawa Tengah, Negara \\ 2 IAIN Surakatra, Jawa Tengah, Indonesia \\ 1nurulamalina683@yahoo.com²muh.nashirudin@iain-surakarta.ac.id,
}

\begin{abstract}
Abstrak
Penilitian ini dilakukan bertujuan untuk mendeskripsikan tentang implementasi standar proses dalam pembelajaran Bahasa Arab di Pondok Pesantren Ta'mirul Islam Surakarta yang meliputi: (1) perencanaan proses pembelajaran Bahasa Arab berupa pengembangan silabus dan rencana pembelajaran (RPP), (2) pelaksanaan pembelajaran Bahasa Arab, dan (3) faktor penghambat dalam perencanaan dan pelaksanaan pembelajaran Bahasa Arab beserta alternatif solusi. Penelitian ini bersifat deskritif kualitatif. Teknik pengambilan data menggunakan metode wawancara, observasi, dan dokumentasi. Berdasaran hasil analisis data disimpulkan sebagai berikut: 1) Silabus mata pelajaran ilmu kebahasaan yang digunakan merujuk pada silabus Pondok Modern Gontor. Sedangkan, proses pembuatan rencana pengajaran Bahasa Arab disusun secara mandiri oleh guru pengajar. Akan tetapi, pembuatan rencana pembelajaran tersebut berjalan kurang optimal. 2) Pelaksanaan proses pembelajaran yang dilakukan sudah cukup standar, mulai dari jumlah peserta didik, alokasi waktu setiap pertemuan, jumlah buku teks dan pelaksanaan pembelajaran. 3) Adapun faktor penghambat dalam pengembangan silabus antara lain kurangnya koordinasi sesama pengajar mengenai batas materi. Motivasi guru dan kemampuan guru dalam membagi waktu adalah dua faktor utama sebagai penghambat dalam pembuatan rencana pembelajaran. Sedangkan, faktor penghambat dalam pelaksanaan pembelajaran antara lain jaranganya guru meninjau pembelajaran sebelumnya, metode mengajar guru masih monoton yang berdampak pada suasana belajar kurang menarik. Adapun solusi yang ditawarkan antara lain perlu adanya usaha untuk meningkatkan motivasi guru secara intensive dan perlu diadakan kegiatan supervisi kelas.
\end{abstract}

Kata kunci: Standar proses; pembelajaran bahasa Arab; dan Pondok Pesantren Ta'mirul Islam Surakarta. 


\begin{abstract}
The current research intends to describe about the implementation of teaching standard process in Arabic Language subject in Ta'mirul Islam Islamic Boarding School Surakarta consisting of (1) lesson preparation in Arabic Language consisting syllabus and lesson plan, (2) the teaching implementation in Arabic Language, and (3) the inhibit factors in Arabic Language teaching preparation and implementation including their alternative solutions. The current research is a qualitative descriptive. The data are collected through interview, observation, and documentation. Based on data analysis, the current research found that: 1) the syllabus used for language subjects are adapted from Pondok Modern Gontor. Meanwhile, lesson plans for Arabic Language subject are formulated by teachers themselves individually. It is found that the lesson plan formulations are not working optimally. 2) Teaching implementations are conducted standardized enough, such as the number of students, time allocation, textbooks, and teaching process. 3) one of the barrier factors for syllabus formulation is the lack of coordination among teachers about the scope of teaching materials. Teacher motivation and teacher time management are among two factors inhibit lesson plan formulations. Meanwhile, factors that inhibit the implementation of teaching processes such as lack of material review by teachers and monotonous teaching method affecting the attraction of teaching process. The recommended solution to overcome those barriers are making an endeavor to enhance teacher motivation and conducting class supervision.
\end{abstract}

Keywords: Standard process; Arabic Language Learning; dan Ta'mirul Islam Islamic Boarding School Surakarta.

\title{
PENDAHULUAN
}

Pendidikan memiliki peranan penting dalam mengembangkan potensi sumber daya manusia secara optimal karena pendidikan merupakan sarana investasi untuk meningkatkan pengetahuan, ketrampilan dan keahlian sebagai modal pembangunan bangsa. Pihak pemerintah juga terus berupaya untuk meningkatkan kualitas pembangunan pendidikan,melalui pengembangan dan perbaikan sarana pendidikan, kurikulum dan sistem evaluasi, pengadaan materi ajar, serta pelatihan guru dan tenaga pendidikan lainnya.

Untuk meningkatkan efisiensi dan efektivitas kompetensi kelulusan, perlu adanya proses pembelajaran yang standar dan ini bisa mengacu pada standar 
Amalina, N.H., \& Nashirudin, M.. (2017). ANALISIS PROSES PEMBELAJARAN BAHASA ARAB PADA TINGKAT $\begin{array}{lllll}\text { TSANAWIYAH DI PONDOK PESANTREN TA'MIRUL ISLAM. 15(2). Retrieved } & \end{array}$ from http://ejurnal.iainmataram.ac.id/index.php/tatsqif/article/view/1185

proses nasional. Standar proses merupakan salah satu dari delapan Standar Nasional Pendidikan yang harus dikembangkan. Dalam Peraturan Menteri Pendidikan dan Kebudayaan Republik Indonesia Nomor 65 Tahun 2013 Tentang Standar Proses Pendidikan Dasar dan Menengah Bab I menyatakan bahwa standar proses adalah kriteria mengenai pelaksanaan pembelajaran pada satuan pendidikan untuk mencapai standar kompetensi kelulusan. Standar proses terdiri dari perencanaan proses pembelajaran, pelaksanaan proses pembelajaran, penilaian hasil pembelajaran, dan pengawasan proses pembelajaran.

Pada dasarnya pelaksanaan standar proses dalam pembelajaran dimaksudkan untuk memberikan pelayanan maksimal dalam pengelolaan pendidikan. Dengan dilaksanakannya proses pembelajaran yang maksimal diharapkan dapat mewujudkan pendidikan yang berkualitas bagi kebutuhan peserta didik dan masyarakat. (Narwanti dan Somadi, 2012:1)

Dalam mengimplementasikan standar proses pada setiap satuan pendidikan perlu memahami sekurang-kurangnya tiga hal,yang pertama pemahaman dalam perencanaan program pendidikan, yaitu pemahaman isi kurikuum, silabus dan pembuatan RPP (Rencana Pelaksanaan Pembelajaran). Kedua pemahaman dalam pengelolaan pembelajaran, dan ketiga pemahaman tentang evaluasi, baik evaluasi proses maupun hasil pembelajaran. (Nurochim, 2013:2)

Begitu juga dalam proses pembelajaran Bahasa Arab, guru pengajar bahasa Arab perlu memperhatikan beberapa hal dalam proses pembelajaran. Ada beberapa alasan untuk mempelajari bahasa Arab, yaitu bahasa Arab merupakan bahasa Al-Qur'an yang dipelajari agar dapat memahami atau menafsirkan ayat Al-Qur'an, hadist serta teks-teks yang menggunakan bahasa Arab. Dan secara politis-internasional bahasa Arab kini diakui sebagai bahasa internasional dan digunakan sebagai salah satu bahasa diplomasi resmi di forum PBB, karena negara Timur Tengah memiliki kekayaan minyak bumi dan bahan pertambangan yang melimpah ruah sehingga menjadikan negara 
Amalina, N.H., \& Nashirudin, M.. (2017). ANALISIS PROSES PEMBELAJARAN BAHASA ARAB PADA TINGKAT $\begin{array}{lllll}\text { TSANAWIYAH DI PONDOK PESANTREN TA'MIRUL ISLAM. 15(2). Retrieved } & \end{array}$ from http://ejurnal.iainmataram.ac.id/index.php/tatsqif/article/view/1185

ini sebagai mitra bisnis level dunia. (Zulhannan, 2014:4)

Pesantren merupakan salah satu lembaga pendidikan Islam yang pada umumnya menyelenggarakan berbagai satuan pendidikan baik secara formal maupun informal. Begitu juga dalam proses pembelajaran, dibutuhkan standar proses dalam pembelajaran untuk meningkatkan tingkat kelulusan serta mutu kualitas peserta didik. (Aly, 2011:8) Pondok Pesantren Ta'mirul Islam adalah salah satu lembaga pendidikan Islam di Surakarta yang menerapkan bahasa Arab maupun inggris dalam percakapan sehari-hari, dan sebagian besar materi yang diajarkan menggunakan bahasa arab, seperti Durūsu al-lughoh dan Dirāsatu al-ilāmiyyatu.

Dalam mengajar materi bahasa arab membutuhkan persiapan yang matang terlebih dalam pembuatan RPP atau I'dad tadris. Di buku i'dadlah para guru menuliskan semua bahan materi yang akan disampaikan, sehingga ketika proses pelaksanaan pembelajaran apa yang akan disampaikan guru jelas dan terkonsep. Dengan kata lain RPP atau i'dadu at-tadris berperan sebagai scenario dalam kegiatan proses pembelajaran.

Menurut pengamatan penulis, pembuatan RPP atau i'dad mengajar di Pondok Pesantren Ta'mirul Islam dibuat secara mandiri oleh para guru pengajar kemudian RPP tersebut dikoreksikan kepada Direktur KMI atau tim korektor yang telah dibentuk oleh Wakil direktur KMI. Kegiatan ini bertujuan untuk meminimalisir kesalahan dalam pembuatan RPP. Kurang aktifnya guru pengajar bahasa Arab dalam membuat RPP sangatlah berpengaruh pada proses pembelajaran, baik dari segi penyampaian materi maupun pembagian waktu pada setiap pertemuan. Begitu pula dalam pelaksanaan pembelajaran, gaya guru mengajarkan materi terlalu monoton, kurang kreatif dan inovatif sehingga suasana belajar kurang asyik dan menarik.

Berangkat dari itu, menjadi sesuatu hal yang menarik untuk dikaji tentang implementasi standar proses pembelajaran bahasa arab di Pondok Pesantren Ta'mirul Islam terlebih intensif dalam perencanaan pembelajaran (pembuatan silabus dan RPP) dan pelaksanaan proses pembelajarannya. 


\section{LANDASAN TEORI}

\section{Standar Proses}

Peratuan Pemerintah No.19 Tahun 2005 Bab 1 Pasal 1 Ayat 6 tentang Standar Nasional Pendidikan menyatakan bahwa standar proses dapat diartikan sebagai suatu bentuk teknis yang merupakan acuan atau kriteria yang dibuat secara terencana atau di desain dalam pelaksanaan pembelajaran pada satu satuan pendidikan untuk mencapai standar kompetensi lulusan. Standar Proses terdiri dari empat aspek yaitu perencanaan proses pembelajaran, pelaksanaan proses pembelajaran, penilaian hasil pembelajaran, dan pengawasan proses pembelajaran.

Dari keempat komponen standar proses yang sudah dijelaskan diatas, peneliti ingin memfokuskan pokok pembahasan pada proses perencanaan pembelajaran dan pelaksanaan pembelajaran. Karena menurut pengamatan peneliti proses penilaian dan pengawasan yang dilakukan di Pondok Pesantren Ta'mirul Islam sudah standar dan cukup optimal.

Seorang guru sebelum melakukan kegiatan pembelajaran harus membuat perencanaan pembelajaran terlebih dahulu. (Majid, 2008:17) Peraturan Pemerintah No.19 Tahun 2005 menyatakan bahwa perencanaan pembelajaran dirancang dalam bentuk silabus dan RPP (Rencana Pelaksanaan Pembelajaran) yang mengacu pada standar isi.

Silabus adalah rencana pembelajaran pada suatu kelompok mata pelajaran atau tema tertentu yang mencakup standar kompetensi, kompetensi dasar, materi pokok atau pembelajaran, kegiatan pembelajaran, indikator, penilaian, alokasi waktu, dan sumber atau bahan belajar. Serta merupakan acuan penyusun kerangka pembelajaran untuk setiap bahan kajian mata pelajaran dan berperan sebagai pengembang rencana proses pendidikan yang memuat identitas mata pelajaran atau tema pelajaran. Pengembangan silabus juga dapat dilakukan oleh para guru secara mandiri atau berkelompok dalam 
Amalina, N.H., \& Nashirudin, M.. (2017). ANALISIS PROSES PEMBELAJARAN BAHASA ARAB PADA TINGKAT $\begin{array}{lllll}\text { TSANAWIYAH DI PONDOK PESANTREN TA'MIRUL ISLAM. 15(2). Retrieved } & \end{array}$ from http://ejurnal.iainmataram.ac.id/index.php/tatsqif/article/view/1185

sebuah sekolah madrasah, kegiatan ini biasanya disebut dengan Musyawarah Guru Mata pelajaran (MGMP). (Narwanti dan Somadi, 2012:1)

Peraturan Menteri Pendidikan Dan Kebudayaan RI Nomor 65 Tahun 2013 Tentang Standar Proses BAB III menyatakan bahwa RPP (Rencana Pelaksanaan Pembelajaran) adalah rencana kegiatan pembelajaran tatap muka untuk satu pertemuan atau lebih. RPP dikembangkan dari silabus untuk mengarahkan kegiatan pembelajaran peserta didik dalam upaya mencapai Kompetensi Dasar (KD). Rencana Pelaksanaan Pembelajaran (RPP) paling sedikit memuat tujuan pembelajaran, materi pembelajaran, metode pembelajaran, sumber belajar, dan penilaian. (Fathurrohman dan Sulistyorini, 2012:102)

Pelaksanaan Pembelajaran terdiri dari dua aspek yang perlu diketahui yaitu: 1) Persyaratan pelaksanaan proses pembelajaran yang terdiri dari jumlah peserta didik, alokasi waktu jam tatap muka pembelajaran, buku teks, dan pengelolaan kelas. 2) Pelaksanaan pembelajaran yang terdiri dari kegiatan pendahuluan, kegiatan inti, dan kegiatan penutup. Jumlah standar peserta didik SMP/MTs setiap kelas 32 anak, dan alokasi waktu setiap jam tatap muka yaitu 40 menit. Jumlah buku teks pelajaran disesuaikan dengan kuota peserta didik, agar semua peserta didik dapat mengikuti pelajaran dengan baik dan nyaman. Dalam pengelolaan kelas guru berperan sebagai narasumber dan fasilitator bagi peserta didik, serta guru dianjurkan untuk menciptakan suasana ketertiban, kedisiplinan, dan kenyamanan selama proses pembelajaran. Pada tiap awal semester, guru menjelaskan silabus mata pelajaran kepada peserta didik.

Pelaksanaan pembelajaran meliputi: 1) kegiatan pendahululan, dimana guru menyiapkan peserta didik secara psikis dan fisik untuk mengikuti proses pembelajaran, mengajukan pertanyaan-pertanyaan yang mengkaitkan pengetahuan sebelumnyadengan materi yang akan 
Amalina, N.H., \& Nashirudin, M.. (2017). ANALISIS PROSES PEMBELAJARAN BAHASA ARAB PADA TINGKAT TSANAWIYAH DI PONDOK PESANTREN TA'MIRUL ISLAM. 15(2). Retrieved from http://ejurnal.iainmataram.ac.id/index.php/tatsqif/article/view/1185

dipelajari, serta menjelaskan tujuan pembelajaran. 2) kegiatan inti, dalam kegiatan inti menggunakan model pembelajaran, metode pembelajaran, media pembelajaran, dan sumber pembelajaran yang disesuaikan dengan karakteristik peserta didik dan mata pelajaran. 3) kegiatan penutup, dalam kegiatan ini guru bersamapeserta didik melakukan refleksi yang bersifat evaluasi baik secara lisan maupun pemberian tugas. Tak lupa guru menginformasikan mengena rencana kegiatan pembelajaran untuk pertemuan berikutnya.

\section{Pembelajaran Bahasa Arab}

Pembelajaran bahasa Arab yaitu proses penyampaian ilmu pengetahuan oleh guru kepada peserta didik dengan menggunakan bahasa Arab, yang bertujuan agar peserta didik dapat memahami dan menguasai bahasa Arab serta dapat mengembangkannya. (Anshor, 2009:6) Kegiatan Belajar Mengajar (KBM) dirancang mengikuti prinsipprinsip belajar mengajar dan prinsip motivasi dalam belajar bahasa Arab.

Ada tiga prinsip yang perlu diperhatikan dalam pembelajaran bahasa Arab (Abdul Hamid, 2010:166), yaitu: 1) Prinsip perencanaan, sebelum melakukan suatu proses pembelajaran bahasa Arab, guru menyiapkan bahan ajar yang akan diberikan kepada peserta didik terlebih dahulu. (Azhar Arsyad, 2004:28) 2) Prinsip pelaksanaan, ada beberapa hal yang perlu diperhatikan oleh guru yaitu tahapan-tahapan dalam penyampaian materi yang akan diajarkan kepada peserta didik. 3) Prinsip evaluasi, setelah melakukan serangkaian proses pembelajaran, perlu adanya evaluasi untuk mengetahui sejauh mana tingkat keberhasilan yang telah dicapai dari proses pembelajaran. (Mulyasa, 2006:255)

Metode pengajaran adalah cara-cara pelaksanaan dari proses pengajaran, atau bagaimana teknisnya suatu bahan pelajaran diberikan kepada peserta didik di sekolah. Makin tepat metodenya, maka upaya dalam pencapaian tujuan pengajaran semakin efektif. Menurut Tayar Yusuf dan Syaiful Anwar (1997) yang dikutip oleh Muhtadi Anshor 
Amalina, N.H., \& Nashirudin, M.. (2017). ANALISIS PROSES PEMBELAJARAN BAHASA ARAB PADA TINGKAT TSANAWIYAH DI PONDOK PESANTREN TA'MIRUL ISLAM. 15(2). Retrieved from http://ejurnal.iainmataram.ac.id/index.php/tatsqif/article/view/1185

(2009), ada beberapa metode pengajaran bahasa Arab, yaitu 1) Metode muhādatsah (bercakap-cakap) yaitu cara menyajikannya melalui percakapan antara guru dengan peserta didik atau sesama peserta didik, sehingga dapat memperkaya vocabulary tentang bahasa Arab. 2) Metode muthāla'ah (membaca) merupakan suatu metode pembelajaran yang cara menyajikan pelajaran dengan cara membaca. 3) Metode imlä' (dikte) yaitu di mana guru membacakan materi pelajaran dan peserta didik menulisnya di buku tulis masing-masing. 4) Metode insyā'(mengarang) yaitu cara menyajikan bahan pelajaran dengan cara menyuruh siswa mengarang dalam bahasa Arab. 5) Metode mahfūzhāt (menghafal), cara menyajikan materi ini yaitu dengan cara menyuruh peserta didik untuk menghafal kalimat-kalimat seperti syair, cerita, kata-kata hikmah dan lain-lain (Zarkasyi, 2004:28), 6) Metode qawā'id (nahwu sharaf), cara penyampaiannya dengan menjelaskan dan menghafalkan kaidah-kaidah tata bahasa Arab yang mencakup nahwu sharaf. (Wa muna, 2011:75)

\section{METODE}

Penelitian ini merupakan penelitian desktiptif kualitatif. Penelitian ini dilakukan di Pondok Pesantren Ta'mirul Islam yang berada di Kabupaten Surakarta. Subjek dalam penelitian ini adalah guru pengajar bahasa Arab Pondok Pesantren Ta'mirul Islam. Sedangkan informan adalah direktur KMI (Kulliyatul Mu'alimāt al-Islāmiyyah), Wakil direktur Kurikulum, Wakil Direktur KBM, Guru supervisor dan santriwati tingkat Tsanawiyah.

Dalam pengumpulan data peneliti menggunakan beberapa metode penelitian, yaitu wawancara, observasi, dan dokumentasi. Untuk memeriksa keabsahan data peneliti menggunakan teknik triangulasi sumber dan metode. Sedangkan, analisis data yang digunakan termasuk jenis analisis interaktif yang terdiri dari reduksi data, penyajian data, dan verifikasi atau kesimpulan. 


\section{HASIL DAN PEMBAHASAN}

1. Perencanaan proses pembelajaran bahasa arab di Pondok Pesantren Ta'mirul Islam

a. Pembuatan silabus

Pondok Pesantren Ta'mirul Islam merupakan salah satu pondok pesantren mu'adalah jenis mu'allimin yang mana program pendidikannya setara dengan madrasah 'aliyah. Kurikulum yang diterapkan adalah Kurikulum Satuan Pendidikan Mu'adalah Jenis Mu'allimin yang dibukukan menjadi Kerangka Dasar dan Struktur Kurikulum Satuan Pendidikan Mu'adalah Mu'allimin. Silabus terdiri dari kompetensi inti, kompetensi dasar, mata pelajaran, materi pokok, pembelajaran, penilaian, alokasi waktu, dan sumber belajar. Sedangkan pembagian materi pada setiap mata pelajaran banyak mengadopsi dari silabus Pondok Gontor.

Pembuatan silabus di Pondok Pesantren Ta'mirul Islam disusun sesuai denga Peraturan Menteri Pendidikan dan Kebudayaan Republik Indonesia Nomor Indonesia Nomor 65 Tahun 2013 Tentang Standar Proses Pendidikan Dasar Dan Menengah, BAB III perihal tentang Perencanaan Proses Pembelajaran, menjelaskan bahwa silabus merupakan acuan kerangka pembelajaran untuk setiap bahan kajian mata pelajaran.

Dalam silabus hanya tercakup mata pelajaran yang harus diajarkan selama waktu setahun atau satu semester.Komponen yang terdapat dalam silabus yaitu standar kompetensi (SK) dan kompetensi dasar (KD). Standar Kompetensi (SK) berisikan sekumpulan kompetensi dasar yang harus dikuasai peserta didik disuatu jenjang pendidikan tertentu. Sedangkan Kompetensi Dasar (KD) merupakan sejumlah kemampuan yang harus dikuasai peserta didik dalam mata pelajaran tertentu sebagai rujukan penyusunan indikator kompetensi dalam suatu pelajaran yang meliputi indikator 
pencapaian kompetensi, tujuan pembelajaran, materi pembelajaran, alokasi waktu, kegiatan pembelajaran, penilaian hasil belajar, dan sumber belajar. (Wina, 2010:4)

b. Pembuatan RPP

Proses pembuatan RPP atau I'dad at-tadris pengajar bahasa Arab di Pondok Pesantren Ta'mirul Islam dibuat secara mandiri oleh para guru pengajar kemudian RPP tersebut dikoreksikan kepada Direktur KMI atau tim korektor yang telah dibentuk oleh Wadir KBM. I'dad attadris atau RPP yang standar seperti penilaian pada supervisi kelas, yang terdiri dari mencantumkan identitas mata pelajaran (penulisan kelas, mata pelajaran, materi, dan alokasi waktu), tujuan pembelajaran (ghordhu 'am dan ghordhu khos), pelaksanaan pembelajaran: kegiatan pendahuluan, kegiatan inti, kegiatan penutup, dan penandatangan I'dad at-tadris atau RPP.

Hal ini dikuatkan oleh Peraturan Pemerintah Nomor 19 Tahun 2005 tentang format RPP, yaitu dalam pembuatan Rencana Pelaksanaan Pembelajaran (RPP) paling sedikit memuat tujuan pembelajaran, materi pembelajaran, metode pembelajaran, sumber belajar, dan penilaian. RPP merupakan rencana kegiatan pembelajaran tatap muka untuk satu pertemuan atau lebih. (Suyono dan Hariyanto, 2015:257)

2. Pelaksanaan pembelajaran bahasa arab di Pondok Pesantren Ta'mirul Islam

a. Persyaratan Pelaksanaan Proses Pembelajaran

Jumlah anak per-kelas pada santri tingkat tsanawiyah di Pondok Pesantren Ta'mirul Islam rata-rata sebanyak 25-27 anak, dan jumlah waktu setiap pertemuan yaitu 40 menit. Begitu juga dengan buku teks pelajaran, buku yang digunakan untuk mata pelajaran bahasa Arab cetakan Darussalam Press dan buku yang disediakan sudah sesuai dengan kebutuhan santri. 
Hal tersebut sesuai dengan persyaratan pelaksanaan proses pembelajaran yang ditetapkan pada Peraturan Menteri Pendidikan Nasioanal Dan Kebudayaan Republik Indonesia Nomor 65 Tahun 2013 Tentang Standar Proses Pendidikan Dasar Dan Menengah, yang menjelaskan bahwa persyaratan dalam pelaksanaan proses pembelajaran pada tiap tingkatan peserta didik. Bagi anak SMP/MTs maksimal jumlah anak per-kelas sebanyak 30 anak, dan alokasi waktu setiap jam pertemuan selama 40 menit.Buku teks pelajaran atau sumber belajar jumlahnya harus disesuaikan dengan kebutuhan peserta didik.

b. Pelaksanaan Pembelajaran

Pelaksanaan pembelajaran merupakan implementasi dari RPP yang terdiri dari kegiatan pendahuluan, kegiatan inti, dan kegiatan penutup, berikut beberapa langkah yang dilakukan pada pelaksanaan pembelajaran bahasa Arab di Pondok Pesantren Ta'mirul Islam:

1) Kegiatan pendahuluan

Pada awal pertemuan para guru pengajar bahasa Arab membahas tentang materi yang akan diajarkan selama satu semester ke depan sesuai dengan silabus. Kemudian di minggu pertemuan selanjutnya guru pengajar bahasa Arab mengawali pertemuannya dengan menanyakan kabar, membaca absen kehadiran, serta memberikan pertanyaan mengenai materi yang telah diajarkan di pertemuan lalu.

Hal tersebut didukung oleh Peraturan Menteri Pendidikan Nasional Dan Kebudayaan Republik Indonesia Nomor 65 Tahun 2013 Tentang Standar Proses Pendidikan Dasar Dan Menengah, Bab IV hal pelaksanaan pembelajar. Disana menjelaskan bahwa dalam kegiatan pendahuluan hal yang perlu diperhatikan guru, yaitu menyiapkan peserta didik secara psikis dan fisik untuk mengikuti 
proses pembelajaran dan memberi motivasi belajar kepada peserta didik secara kontekstual sesuai dengan materi yang diajarkan. Sebelum dimulai meteri baru alangkah baiknya guru mengajukan pertanyaan yang mana mengkaitkan pengetahuan sebelumnya dengan materi yang akan dipelajari, selanjutnya menjelaskan tujuan pembelajaran atau kompetensi dasar yang akan dicapai.

2) Kegiatan inti

Pada kegiatan ini guru pengajar bahasa Arab di Pondok Pesantren Ta'mirul Islam memberikan umpan balik secara lisan, yaitu menanyakan kepada santri hal yang belum dimengerti dari materi yang diajarkan atau pengetahuan yang lain untuk mengembangkan pemahaman santri. Waktu seperti inilah guru berperan penting sebagai narasumber dan dan fasilitator dalam menjawab pertanyaan santri. Metode yang diterapkan merujuk pada pedoman buku Tarbiyah Amaliyah, akan tetapi guru pengajar diperbolehkan untuk mengembangkan metode tersebut.

Kegiatan tersebut didukung oleh Peraturan Menteri Pendidikan Nasional Dan Kebudayaan Republik Indonesia Nomor 65 Tahun 2013, yang menjelaskan bahwapada kegiatan inti menggunakan model pembelajaran, metode pembelajaran, media pembelajaran, dan sumber belajar yang disesuaikan dengan karakteristik peserta didik dan mata pelajaran, yang meliputi proses eksplorasi, elaborasi dan konfirmasi. (Suyono dan Hariyanto, 2015: 260-261)

3) Kegiatan penutup

Pada kegiatan penutup terdapat beberapa jenis evaluasi yang diberikan guru pengajar bahasa Arab di Pondok Pesantren Ta'mirul Islam sebelum mengakhir pertemuannya, antara lain pertanyaan secaralisan, pemberian tugas menjawab tamrinat atau soal, menggunakan sisa waktu untuk hafalan materi yang baru 
disampaikan, dan memberikan motivasi untuk meningkatkan rasa keingintahuan santri akan ilmu pengetahuan.

Kegiatan tersebut didukung oleh Peraturan Menteri Pendidikan Nasional Dan Kebudayaan Republik Indonesia Nomor 65 Tahun 2013, yang menjelaskan bahwa dalam kegiatan penutup guru bersama peserta didik, baik secara individual maupun kelompok melakukan beberapa refleksi untuk mengevaluasi, seperti memberikan umpan balik terhadap proses dan hasil pembelajaran, melakukan kegiatan tindak lanjut dalam bentuk pemberian tugas, baik tugas individual maupun kelompok, dan juga menginformasikan rencana kegiatan pembelajaran untuk pertemuan berikutnya.

3. Faktor penghambat dan solusi dalam perencanaan proses pembelajaran dan pelaksanaan pembelajaran bahasa arab di Pondok Pesantren Ta'mirul Islam

a. Perencanaan proses pembelajaran

1) Pembuatan silabus

Dalam proses pembuatan silabus mata pelajaran terdapat beberapa faktor penghambat, yaitu kurang disiplinnya para pengajar dalam memberikan materi ketika mengajar, kurangnya koordinasi antara sesama pengajar materi, banyaknya kesibukan atau agenda pondok selama awal semester sehingga memotong aktifitas belajar, dan kurangnya informasi mengenai problematika selama proses pembelajaran dari guru mata pelajaran yang tidak hadir dalam Musyawarah Guru Mata Pelajaran.

Solusi dari faktor penghambat tersebut yaitu dengan mengadakan program Musyawarah Guru Mata Pelajaran (MGMP) serta menegaskan bagi para guru mapel yang tidak hadir dalam musyawarah, mengadakan rapat sebelum ujian berlangsung, dan adanya pengecekan I'dad secara berkala agar pihak KMI mengetahui sudah berapa persen guru mengajarkan materi sesuai silabus. 


\section{2) Pembuatan I'dad tadris atau RPP}

Adapun beberapa faktor penghambat dalam proses pembuatan I'dad tadris atau RPP, yaitu kurangnya motivasi yang diberikan untuk ustdzah dalam, kurangnya kemampuan ustadzah dalam membagi waktu, dan tugas mengajar belum tertanam di jiwa mereka. Karena tugas mereka bukan hanya mengajar, akan tetapi belajar dan membantu pondok.

Solusi dari penghambat tersebut antar lain memberikan motivasi, mengadakan kegiatan supervisi, dan adanya buku guru untuk semua mata pelajaran seperti halnya di sekolah lain pada umumnya.

b. Pelaksanaan pembelajaran

Adapun beberapa faktor penghambat selama pelaksanaan pembelajaran yaitu kurang aktifnya guru pengajar dalam menanyakan materi lalu sebelum memulai atau menambah materi baru, kurangnya guru menggunakan media belajar saat menjelaskan materi, dan gaya guru mengajarkan materi terlalu monoton, kurang kreatif dan inovatif sehingga suasana belajar kurang menarik.

Solusi yang tepat untuk mengatasi faktor penghambat tersebut yaitu dengan mengadakan supervisi kelas. Karena dengan adanya evaluasi guru mengetahui kekurangannya dalam mengajar dan supervisor memberi masukan atas kekurangannya, dengan tujuan untuk meningkatkan kompetensi guru dalam mengajar. Sehingga kedepannya akan lahir guru-guru yang professional.

\section{KESIMPULAN}

1. Perencanaan proses pembelajaran bahasa arab di Pondok Pesantren Ta'mirul Islam

a. Pembuatan silabus sudah sesuai dengan Peraturan Menteri Pendidikan Nasional Dan Kebudayaan Republik Indonesia Nomor 65 
Tahun 2013 Tentang Standar Proses Pendidikan Dasar Dan Menengah, baik dari segi penyusunannya maupun implementasinya.

b. Pembuatan RPP bahasa Arab pada santri tingkat tsanawiyah di Pondok Pesantren Ta'mirul Islam berjalan kurang optimal, khususnya para guru pondok. karena padatnya kegiatan pondok, dan guru pondok kurang mampu membagi waktu

2. Pelaksanaan proses pembelajaran bahasa arab di Pondok Pesantren Ta'mirul Islam sudah berjalan cukup baik, akan tetapi adanya beberapa kekurangan yaitu kurang media pembelajaran ketika menjelaskan materi, dan cara mengajar guru terlalu monoton sehingga membuat suasana belajar kurang asyik dan menarik.

3. Faktor penghambat dan solusi dalam perencanaan proses pembelajaran dan pelaksanaan pembelajaran bahasa arab di Pondok Pesantren Ta'mirul Islam

a. Perencanaan proses pembelajaran

1) Pembuatan silabus

Dalam proses pembuatan silabus mata pelajaran terdapat beberapa faktor penghambat, yaitu kurang disiplinnya para pengajar dalam memberikan materi ketika mengajar, kurangnya koordinasi antara sesama pengajar materi, banyaknya kesibukan atau agenda pondok selama awal semester sehingga memotong aktifitas belajar, dan kurangnya informasi mengenai problematika selama proses pembelajaran dari guru mata pelajaran yang tidak hadir dalam Musyawarah Guru Mata Pelajaran.

Solusi dari faktor penghambat tersebut yaitu dengan mengadakan program Musyawarah Guru Mata Pelajaran (MGMP) serta menegaskan bagi para guru mapel yang tidak hadir dalam musyawarah, mengadakan rapat sebelum ujian berlangsung, dan adanya pengecekan I'dad secara berkala agar pihak KMI mengetahui sudah berapa persen guru mengajarkan materi sesuai silabus.

2) Pembuatan I'dad tadris atau RPP 
Adapun beberapa faktor penghambat dalam proses pembuatan I'dad tadris atau RPP, yaitu kurangnya motivasi yang diberikan untuk ustdzah dalam, kurangnya kemampuan ustadzah dalam membagi waktu, dan tugas mengajar belum tertanam di jiwa mereka. Karena tugas mereka bukan hanya mengajar, akan tetapi belajar dan membantu pondok.

Solusi dari penghambat tersebut antar lain memberikan motivasi, mengadakan kegiatan supervisi, dan adanya buku guru untuk semua mata pelajaran seperti halnya di sekolah lain pada umumnya.

b. Pelaksanaan pembelajaran

Adapun beberapa faktor penghambat selama pelaksanaan pembelajaran yaitu kurang aktifnya guru pengajar dalam menanyakan materi lalu sebelum memulai atau menambah materi baru, kurangnya guru menggunakan media belajar saat menjelaskan materi, dan gaya guru mengajarkan materi terlalu monoton, kurang kreatif dan inovatif sehingga suasana belajar kurang menarik. Solusi yang tepat untuk mengatasi faktor penghambat tersebut yaitu dengan mengadakan supervisi kelas.

\section{DAFTAR PUSTAKA}

Ali, Mohammad. 2014. Metodologi dan Aplikasi Riset Pendidikan. Bumi Akasara: Jakarta

Alwi, Hasan. 2001. Kamus Besar Bahasa Indonesia. Jakarta: Balai Pustaka.

Aly, Abdullah. 2011. Pendidikan Islam Multikultural Di Pesantren. Yogjakarta: Pustaka Pelajar

Anshor, Muhtadi Ahmad. 2009. Pengajaran Bahasa Arab Media dan MetodeMetodenya. Yogjakarta: Teras.

Arsyad, Azhar. 2002. Media Pembelajaran. Jakarta: Raja Grafindo Persada 
Amalina, N.H., \& Nashirudin, M.. (2017). ANALISIS PROSES PEMBELAJARAN BAHASA ARAB PADA TINGKAT $\begin{array}{lllll}\text { TSANAWIYAH DI PONDOK PESANTREN TA'MIRUL ISLAM. 15(2). Retrieved } & \end{array}$ from http://ejurnal.iainmataram.ac.id/index.php/tatsqif/article/view/1185 2004. Bahasa Arab dan Metode Pengajaran. Yogjakarta: Pustaka Pelajar.

Fathurrohman, Muhammad dan Sulistyorini. 2012. Belajar dan Pembelajaran Meningkatkan Mutu Pembelajaran Sesuai Standar Nasional. Yogjakarta: Teras

Hadi, Sutrisno. 2015. Metodologi Riset. Yogjakarta: Pustaka Pelajar Offset

Hamid, Abdul dan Baharuddin, Uril. 2008. Pembelajaran Bahasa Arab Pendekatan, Metode, Strategi, Materi dan Media. Malang: UIN-Malang Press.

Haryanto dan Suyono. 2011. Belajar dan Pembelajaran Teori dan Konsep. Bandung: Remaja Rosdakarya

Majid, Abdul. 2008. Perencanaan Pembelajaran Mengembangkan Standar Kompetensi Guru. Bandung: PT Remaja Rosdakarya.

Mulyasa, E. 2006. Kurikulum Yang Disempurnakan. Bandung: Remaja Rosdakarya.

Narwati, Sri dan Somadi. 2012. Panduan Menyusun Silabus dan Perencanaan Pembelajaran. Yogjakarta: Familia

Peraturan Pemerintah Republik Indonesia Nomor 19 Tahun 2005 Tentang Standar Nasional Pendidikan. Jakarta: Departemen Pendidikan Nasional.

Peraturan Pemerintah Agama Republik Indonesia Nomor 2 Tahun 2008 Tentang Standar Kompetensi Lulusan dan Standar Isi Pendidikan Agama Islam Dan Bahasa Arab Di Madrasah. Jakarta: Menteri Agama Republik Indonesia.

Peraturan Menteri Pendidikan Nasioanal Dan Kebudayaan republik Indonesia Nomor 65 Tahun 2013 Tentang Standar Proses Pendidikan Dasar Dan Menengah. Jakarta: Menteri Pendidikan dan Kebudayaan Indonesia.

Purwanto. 2007. Metodologi Penelitian Kuantitatif untuk Psikologi dan Pendidikan. Yogjakarta: Pustaka Pelajar.

Sanjaya, Wina. 2010. Strategi Pembelajaran Berorientasi Standar Proses Pendidikan. Jakarta: Prenada Media Grup. 
Sugiyono. 2010. Metode Penelitian Kuantitatif, Kualitatif Dan R\&D, Bandung: Alfabeta.

Suyono dan Hariyanto. 2015. Implementasi Belajar dan Pembelajaran, Bandung: Remaja Rosdakarya

Sujarweni, Wiratna. 2014. Metodologi Penelitian. Yogjakarta: Pustaka Baru Press.

Sukmadinata, Syaodih Nana. 2010. Metode Penelitian Pendidikan. Bandung: Rosdakarya

Suryana, Yaya. 2015. Metode Penelitian Manajemen Pendidikan. Bandung: Pustaka Setia.

Wa Muna. 2011. Metodologi Pembelajaran Bahasa Arab. Yogjakarta: Sukses Offset.

Zarkasyi, Imam. 2014. At-Tarbiyyatu Al-'Amaliyyatu cetakan ke 4. Ponorogo: Darussalam Press.

Zulhannan. 2014. Teknik Pembelajaran Bahasa Arab Interaktif. Jakarta: Raja Grafindo Persada. 